\title{
Investigation of Organizational Commitment Levels of Physical Education and Classroom Teachers
}

\author{
Ercüment Erdoğan*, Erkan Cavlı \\ School of Physical Education and Sports, Ordu University, Turkey
}

Copyright $(2018$ by authors, all rights reserved. Authors agree that this article remains permanently open access under the terms of the Creative Commons Attribution License 4.0 International License

\begin{abstract}
The aim of this study is to determine physical education teachers' and classroom teachers' organizational commitment levels. Study sample consists of 101 classroom teachers and 101 physical education teachers working in schools affiliated to the Ministry of National Education. Teachers' perceptions of organizational commitment were examined in terms of field of specialization, gender, years of experience, age, marital status and place of duty. Data were collected using Allen and Meyer's Organizational Commitment Scale and a socio-demographic information form. Data were analyzed using the Statistical Package for Social Sciences (SPSS). Normality test, descriptive statistics, Mann Whitney U test, Kruskal Wallis test and Tamhane's T2 test were used. Results show that classroom teachers' normative commitment levels are higher than those of physical education teachers. Female teachers' normative commitment levels are higher than those of male teachers. Continuance commitment levels of teachers working in cities are higher than those of teachers working in districts. Continuance commitment levels of teachers working for 1 to 10 and 11 to 20 years are higher than those of teachers working for over 30 years. Teachers' organizational commitment levels did not differ by age and marital status $(\mathrm{P}>0.05)$. Results indicate that field of specialization, gender, years of experience and place of duty have an effect on physical education teachers' and classroom teachers' organizational commitment levels while age and marital status have no effect on their organizational commitment levels.
\end{abstract}

Keywords Organizational Commitment, Classroom Teacher, Physical Education Teacher

\section{Introduction}

Education plays an important role in shaping the foundations and future of a society. Teachers undoubtedly have the greatest responsibility in this process. Teaching requires a series of mental and physical efforts to raise people's quality of life, to make creative, productive, positive and permanent changes in their behavior and to equip them with skills what will help them meet their needs in the social structure.

Organizational commitment in educational institutions refers to teachers' effectiveness, job satisfaction, and internal motivation and desire. Primary school teachers, therefore, need to be devoted to their organization, profession and students to be able to work effectively and productively. The higher this commitment, the easier it is for teachers to achieve success and to find fulfillment in teaching. The concept of organizational commitment is defined in various ways in the literature. Leong et al. [1] defines organizational commitment as "the strength of an individual's identification with, and involvement in, a particular organization.” Matthews and Shepherd [2] define it as a concept that attempts to explain an individual's attitudes and behavior towards his/her profession. Organizational commitment can be defined in general as the desire of employees to be involved in an organization, and their commitment to organizational goals and values. From a similar vein, organizational commitment can also be regarded as the extent to which one is involved in, and identifies with, one's organization [3]. Organizational commitment can also be defined as one's belief in and affective attachment to the goals and values of an organization, one's readiness to perform above and beyond what is expected of one's role for the benefit of the organization and one's willingness to be a member of the organization [4].

According to Allen and Meyer [5], organizational commitment is a psychological condition that binds an individual to an organization. There are three types of organizational commitment; affective commitment, continuance commitment and normative commitment. Affective commitment is defined, in short, as an emotional attachment to, identification with, and a desire to remain a member of an organization. Continuance commitment is defined as willingness to remain in an organization due to 
personal investments such as good working relationships with coworkers and acquired job skills. Normative commitment is defined as a desire to remain a member of an organization out of a sense of obligation. The individual sees the goals of the organization as his or her own goals and is willing to achieve them out of a sense of morality, and responsibility or obligation.

According to Maslach and Leiter [6], the factors affecting organizational commitment are workload, control, reward, community, fairness and values. Workload can be defined as "the amount of work to be done at a given time and at a certain quality.” Control refers to one's perceived capacity to make choices and decisions that affect one's work, to solve problems and to take responsibilities in organizational life. Reward refers to "financial and social recognition in return for contributions to the organization. Community/sense of unity refers to a characteristic of the social environment of the organization. According to this, people are involved in organizations in which they achieve positive gains such as social support and cooperation. Fairness refers to members' perceptions of the accuracy and rightness of organizational decisions and policies. It is concerned with "the extent to which the organization has consistent and equitable rules for everyone working there." Value, in its simplest form, refers to the belief in what is good and what is bad.

Teachers are expected to perform numerous duties at high levels and to take into account various factors in managing their students' learning. Teaching, therefore, has a wider area of influence than all other occupational groups. To improve the performance of teachers and the quality of education, it is of great importance to detect and eliminate the problems peculiar to the profession of teaching. The aim of this study is to determine primary school physical education teachers' and classroom teachers' organizational commitment levels in terms of some variables.

\section{Materials and Methods}

\subsection{Sampling}

The study sample consisted of 101 classroom teachers(CT) and 101 physical education teachers (PET)working in schools affiliated to the Ministry of National Education.

\subsection{Data Collection}

The demographic information form developed by the researcher consists of information on participants' field of specialization, gender, years of experience, age, marital status and place of duty.

\subsection{Organizational Commitment Scale:}

Allen and Meyer's Organizational Commitment Scale [5] was used to determine participants' organizational commitment levels. The validity and reliability of the scale were established by Balay [7]. The scale consists of 3 subscales; affective commitment (items 1, 2, 3, 4, 5, 6), continuance commitment (items $7,8,9,10,11,12$ ) and normative commitment (items 13, 14, 15, 16, 17, 18). The items in the scale are scored on a 5-point Likert scale; Strongly disagree (1), Disagree (2), Neither agree nor disagree (3), Agree (4), Strongly Agree (5).

Table 1. Organizational Commitment Scale Score Ranges

\begin{tabular}{|c|c|}
\hline Organizational Commitment Level & Score Ranges \\
\hline Strongly Agree & $4.20-5.00$ \\
\hline Agree & $3.40-4.19$ \\
\hline Neither agree nor disagree & $2.60-3.39$ \\
\hline Disagree & $1.80-2.59$ \\
\hline Strongly disagree & $1.00-1.79$ \\
\hline
\end{tabular}

\subsection{Data Analysis}

Data were analyzed using the Statistical Package for Social Sciences (SPSS), version 22. Normality test, descriptive statistics, Mann Whitney U test, Kruskal Wallis test and Tamhane's T2 test were used to analyze the data at a significance level of 0.05 .

\section{Findings}

Participants' normative commitment levels $(\mathrm{p}=0.036)$ significantly differed by field of specialization $(\mathrm{p}<0.05)$. However, their affective commitment $(p=0.956)$ and continuance commitment $(\mathrm{p}=0.960)$ levels did not differ by field of specialization ( $>0.05)$ (Table 2).

Table 2. Analysis Results of Organization Commitment Levels by Field of Specialization

\begin{tabular}{|c|c|c|c|c|c|}
\hline Branch & & $\mathrm{N}$ & Mean & $\begin{array}{l}\text { Std. } \\
\text { Dev. }\end{array}$ & $\mathrm{p}$ \\
\hline \multirow{2}{*}{ Affective commitment } & $\mathrm{CT}$ & 101 & 3,34 & ,056 & \multirow{2}{*}{,956 } \\
\hline & PET & 101 & 3,39 & 059 & \\
\hline \multirow{2}{*}{ Continuance commitment } & $\mathrm{CT}$ & 101 & 3,36 & ,068 & \multirow{2}{*}{ 985, } \\
\hline & PET & 101 & 3,39 & 071 & \\
\hline \multirow{2}{*}{ Normative commitment } & CT. & 101 & 3,36 & ,073 & \multirow{2}{*}{$033^{*}$} \\
\hline & PET. & 101 & 3,17 & 079 & \\
\hline
\end{tabular}

Participants' affective commitment $(\mathrm{p}=0.978)$, continuance commitment $(p=0.493)$ and normative commitment $(p=0.645)$ levels did not differ by age $(p>$ 0.05) (Table 3). 
Table 3. Analysis Results of Organization Commitment Levels by Age

\begin{tabular}{|c|c|c|c|c|}
\hline & Age & $\mathrm{N}$ & Ort \pm Std.Dev & $\mathrm{p}$ \\
\hline \multirow{4}{*}{$\begin{array}{l}\text { Affective } \\
\text { commitment }\end{array}$} & $21-30$ & 93 & $3,38 \pm 0,059$ & \multirow{4}{*}{ 978 } \\
\hline & $31-40$. & 56 & $3,38 \pm 0,074$ & \\
\hline & $41-50$ & 37 & $3,31 \pm 0,097$ & \\
\hline & $51+$ & 16 & $3,38 \pm 0,183$ & \\
\hline \multirow{4}{*}{$\begin{array}{l}\text { Continuance } \\
\text { commitment }\end{array}$} & $21-30$ & 93 & $3,47 \pm 0,070$ & \multirow{4}{*}{,493 } \\
\hline & $31-40$. & 56 & $3,36 \pm 0,099$ & \\
\hline & $41-50$ & 37 & $3,30 \pm 0,098$ & \\
\hline & $51+$ & 16 & $3,05 \pm 0,207$ & \\
\hline \multirow{4}{*}{$\begin{array}{l}\text { Normative } \\
\text { commitment }\end{array}$} & $21-30$ & 93 & $3,21 \pm 0,083$ & \multirow{4}{*}{ 645 } \\
\hline & $31-40$. & 56 & $3,36 \pm 0,099$ & \\
\hline & $41-50$ & 37 & $3,29 \pm 0,105$ & \\
\hline & $51+$ & 16 & $3,19 \pm 0,234$ & \\
\hline
\end{tabular}

There was a statistically significant difference in normative commitment ( $p=0.038$ ) levels between male and female participants ( $\mathrm{p}<0.05)$. However, there was no statistically significant difference in affective commitment $(p=0.525)$ and continuance commitment $(p=0.312)$ levels between them $(\mathrm{p}>0.05)$ (Table 4).

Table 4. Analysis Results of Organization Commitment Levels by Gender

\begin{tabular}{|c|c|c|c|}
\hline Gender & $\mathrm{N}$ & Meant \pm Std.Dev. & $\mathrm{p}$ \\
\hline \multirow{2}{*}{ Affective commitment } & Female 87 & $3,33 \pm 0,059$ & \multirow{2}{*}{, 525} \\
\hline & Male 115 & $3,39 \pm 0,074$ & \\
\hline \multirow{2}{*}{ Continuance commitment } & Female 87 & $3,33 \pm 0,070$ & \multirow{2}{*}{, 327 } \\
\hline & Male 115 & $3,41 \pm 0,099$ & \\
\hline \multirow{2}{*}{ Normative commitment } & Female 87 & $3,36 \pm 0,083$ & \multirow{2}{*}{, 033} \\
\hline & Male 115 & $3,20 \pm 0,099$ & \\
\hline
\end{tabular}

Participants' affective commitment ( $\mathrm{p}=0.421)$, continuance commitment $(p=0.642)$ and normative commitment $(p=0.060)$ levels did not significantly differ by marital status $(\mathrm{p}>0.05)$ (Table 5$)$.

Table 5. Analysis Results of Organization Commitment Levels by Marital Status

\begin{tabular}{ccccc}
\hline \multicolumn{2}{c}{ Marital status } & $\mathrm{N}$ & Mean \pm Std.Dev. & $\mathrm{p}$ \\
\hline \multirow{2}{*}{$\begin{array}{c}\text { Affective } \\
\text { commitment }\end{array}$} & Married & 101 & $3,41 \pm 0,060$ & \multirow{2}{*}{, 421} \\
\cline { 2 - 4 } & Single & 101 & $3,33 \pm 0,055$ & \\
\hline \multirow{2}{*}{$\begin{array}{c}\text { Continuance } \\
\text { commitment }\end{array}$} & Married & 101 & $3,40 \pm 0,068$ & \multirow{2}{*}{, 625} \\
\cline { 2 - 4 } & Single & 101 & $3,35 \pm 0,071$ & \\
\hline $\begin{array}{c}\text { Normative } \\
\text { commitment }\end{array}$ & Married & 101 & $3,35 \pm 0,081$ & \multirow{2}{*}{, 078} \\
\cline { 2 - 4 } & Single & 101 & $3,18 \pm 0,071$ & \\
\hline
\end{tabular}

Participants' continuance commitment ( $\mathrm{p}=0.004)$ levels significantly differed by place of duty $(\mathrm{p}<0.05)$ while their affective commitment $(p=0.109)$ and normative commitment $(\mathrm{p}=0.096)$ levels did not $(\mathrm{p}>$ 0.05) (Table 6).

Table 6. Analysis Results of Organization Commitment Levels by Place of Duty

\begin{tabular}{ccccc}
\hline \multicolumn{2}{c}{ Place of duty } & $\mathrm{N}$ & Mean \pm Std.Dev. & $\mathrm{p}$ \\
\hline \multirow{2}{*}{$\begin{array}{c}\text { Affective } \\
\text { commitment }\end{array}$} & County & 106 & $3,44 \pm 0,059$ & \multirow{2}{*}{109} \\
\cline { 2 - 4 } & District & 96 & $3,28 \pm 0,055$ & \\
\hline \multirow{2}{*}{$\begin{array}{c}\text { Continuance } \\
\text { commitment }\end{array}$} & County & 106 & $3,50 \pm 0,068$ & \multirow{2}{*}{, $004^{*}$} \\
\cline { 2 - 4 } $\begin{array}{c}\text { Normative } \\
\text { commitment }\end{array}$ & District & 96 & $3,23 \pm 0,068$ & \\
\cline { 2 - 4 } & District & 96 & $3,18 \pm 0,072$ & \multirow{2}{*}{096} \\
\hline
\end{tabular}

Participants' continuance commitment $(p=0.018)$ levels significantly differed by years of experience $(\mathrm{p}<$ $0.05)$ while their affective commitment $(p=0.701)$ and normative commitment $(\mathrm{p}=0.072)$ levels did not $(\mathrm{p}>$ 0.05) (Table 7).

Table 7. Analysis Results of Organization Commitment Levels by Years of Experience

\begin{tabular}{cccc}
\hline Years of experience & $\mathrm{N}$ & Mean \pm Std.Dev. & $\mathrm{p}$ \\
\hline \multirow{4}{*}{ Affective commitment } & $1-10$ & 96 & $3,37 \pm 0,061$ \\
\cline { 2 - 4 } & $11-20$. & 52 & $3,48 \pm 0,075$ \\
\cline { 2 - 4 } & $21-30$ & 41 & $3,26 \pm 0,088$ \\
\cline { 2 - 4 } & $31+$ & 13 & $3,25 \pm 0,184$ \\
\hline \multirow{3}{*}{ Continuance commitment } & $1-10$ & 96 & $3,50 \pm 0,074$ \\
\cline { 2 - 4 } & $11-20$. & 52 & $3,42 \pm 0,091$ \\
\cline { 2 - 4 } & $21-30$ & 41 & $3,22 \pm 0,099$ \\
\cline { 2 - 4 } Normative commitment & $31+$ & 13 & $2,76 \pm 0,150$ \\
\cline { 2 - 4 } & $1-10$ & 96 & $3,37 \pm 0,080$ \\
\cline { 2 - 4 } & $11-20$. & 52 & $3,28 \pm 0,111$ \\
\cline { 2 - 4 } & $21-30$ & 41 & $3,10 \pm 0,107$ \\
\hline
\end{tabular}

Participants were divided into 4 groups based on years of experience to determine whether organization commitment levels differed by professional experience (Group 1: 1 to 10 years of experience; Group 2: 11 to 20 years of experience; Group 3: 21 to 30 years of experience and Group 4: more than 30 years of experience). There was a statistically significant difference in normative commitment levels between groups 1 and 4 ( $p=0.002)$, and between groups 2 and $4(\mathrm{p}=0.007)$. There was, however, no statistically significant difference in normative commitment levels between group 1 and groups $2(p=0.988)$ and $3(p=0.153)$, between groups 2 and $3(\mathrm{p}=0.584)$ and between groups 3 and $4(\mathrm{p}=0.108)$ (p > 0.05) (Table 8). 
Table 8. Multiple Comparison Results of Organization Commitment Levels by Years of Experience

\begin{tabular}{|c|c|c|c|c|}
\hline & 1 & $\mathrm{j}$ & $\begin{array}{l}\text { Mean diff. } \\
\text { (I-J) } \pm \text { Std.d }\end{array}$ & $\mathrm{p}$ \\
\hline \multirow{12}{*}{$\begin{array}{l}\text { Continuance } \\
\text { commitment }\end{array}$} & \multirow{3}{*}{$1-10$} & $11-20$. & $0,075 \pm 0,117$ & 988 \\
\hline & & $21-30$ & $0,278 \pm 0,123$ & 153 \\
\hline & & $31+$ & $0,732 \pm 0,167$ &, $002^{*}$ \\
\hline & \multirow{3}{*}{$11-20}$. & $1-10$ & $0,075 \pm 0,117$ & ,988 \\
\hline & & $21-30$ & $0,202 \pm 0,134$ & ,584 \\
\hline & & $31+$ & $0,657 \pm 0,175$ &, $007^{*}$ \\
\hline & \multirow{3}{*}{$21-30$} & $1-10$ & $-0,278 \pm 0,123$ & ,153 \\
\hline & & $11-20$ & $-0,202 \pm 0,134$ & ,584 \\
\hline & & $31+$ & $0,454 \pm 0,180$ & ,108 \\
\hline & \multirow{3}{*}{$31+$} & $1-10$ & $-0,732 \pm 0,167$ &, $002^{*}$ \\
\hline & & $11-20$ & $-0,657 \pm 0,175$ &, $007^{*}$ \\
\hline & & $21-30$ & $-0,454 \pm 0,180$ & 108 \\
\hline
\end{tabular}

\section{Discussion and Conclusions}

Organizational commitment is one of the core activities and final goals for organizations to protect their assets because people with organizational commitment are more adjusted, satisfied, productive, loyal, responsible and cost-effective [8]. One of the most important problems of education system is teachers' reduced positive attitudes towards school and their job, which might be due to social, psychological, physiological, material or organizational reasons. A decrease in organizational commitment may also be one of these reasons. The more their values align with organizational values, the more efficient they become [9].

The results show that continuance commitment is highest followed by affective commitment and normative commitment among participants. According to Brown [10], the most desirable outcome would be when affective commitment was highest followed by normative commitment and continuance commitment among employees.

This study investigated physical education teachers' and classroom teachers' organizational commitment levels. Data from Allen and Meyer's Organizational Commitment Scale [5] and a socio-demographic information were analyzed.

Participants' normative commitment levels significantly differed by area of specialization. Classroom teachers attach more importance to organizational tasks and responsibilities than do physical education teachers. Gören and Yengin Sarpkaya [11] reported significant differences in affective commitment levels between skill course teachers (physical education, technology-design, visual arts, music) and pre-school, classroom and verbal course teachers (Turkish, social studies, culture of religion and knowledge of ethics, foreign language, counseling); significant differences in continuance commitment levels between pre-school and classroom teachers and verbal course teachers; and significant differences in normative commitment levels between verbal course teachers and skill course teachers. Kurşunoğlu et al. [12] also reported that the organizational commitment levels of classroom teachers were significantly higher than those of in-field-teachers. These results are consistent with those of our study. However, Akyol et al. [13] reported no significant difference in organizational commitment levels between physical education teachers and classroom teachers.

Similar to the results of Akyol et al. [13] , participants' organizational commitment levels did not differ by age in this study. Korkmaz [14] and Karakaya and Karademir [15] reported similar results as well. Some studies report that organizational commitment levels differ by age. Gören and Yengin Sarpkaya [11] reported that teachers' affective commitment and normative commitment levels differed by age. Kurşunoğlu et al. [12] reported that affective commitment levels increased with age. Angle and Perry [16]) stated that as employees grow older, their job opportunities become smaller, thus, their organizational commitment increases. Although our results do not show any significant difference in organizational commitment by age, affective commitment levels were found to be higher than normative and continuance commitment levels.

Participants' normative commitment levels significantly differed by gender, indicating that female teachers have higher commitment levels than male teachers. Mc culurg [17], Elizur and Koslowsky [18], and Jackson[19] reported that women have higher organizational commitment levels than men. On the other hand, Kirel [20] and Karrasch [21] concluded that men have more organizational commitment than women. Gören and Yengin Sarpkaya [11] reported that managers' and teachers' normative and continuance commitment levels did not differ by gender, but that male teachers' affective commitment levels were higher than those of female teachers. Danış [22], Durna and Eren [23], Erdoğmuş [24], Boylu, Pelit and Güçer [25], Çakır [26], Özkan [9], and Nartgün and Menep [27] reported no relationship between teachers' gender and their views of organizational commitment.

Research on the relationship between gender and organizational commitment has achieved no consensus on the organizational commitment levels of men and women. Women's organizational commitment is reported to be due to cultural and social differences, values, socio-economic factors and legal arrangements.

Participants' organizational commitment levels did not differ by marital status, which, therefore, does not seem to play any significant role in people's organizational commitment. Çakır [26], Erdoğmuş [24], and Özcan [28]also reported that there was no relationship between 
primary school teachers' marital status and their organizational commitment levels, indicating that the organizational commitment levels of married and single individuals are the same. Contrary to our findings, Özkaya, Kocakoç and Kara [29], Durna and Eren [23], and Benkhoff [30] reported that married individuals have higher organizational commitment levels than single individuals. According to Gündoğan, [31], this is due to the fact that married employees have financial responsibilities to their families, resulting in them experiencing increased organizational commitment for fear of losing their investments and jobs.

Participants' continuance commitment levels significantly differed by years of experience while their affective commitment and normative commitment levels did not. There was a statistically significant difference in continuance commitment scores between participants with 1 to 10 years of experience and those with more than 30 years of experience, and between those with 11 to 20 years of experience and those with more than 30 years of experience. As the number of years of experience increased, their continuance commitment decreased. Selvitopu and Şahin [32] reported that organizational commitment levels increased with an increase in the number of years of experience. Demirsoy [33] reported that physical education teachers' organizational commitment and job satisfaction levels significantly differed by years of experience, indicating that their organizational commitment increased with an increase in the number of years of experience. However, in this study, participants' continuance commitment levels decreased with an increase in the number of years of experience. On the other hand, Yalçın and İplik [34], Erdoğmuş [24], Canpolat [35], Kılıçoğlu [36], Özcan [28], Karakaya and Karademir [15], and Kurşunoğlu et al. [12] reported that years of experience have no effect on organizational commitment levels.

Participants' continuance commitment levels significantly differed by place of duty. Having reported similar results, Akyol et al. [13] account for this difference by the fact that teachers generally want to work in the cities. Generally, all teachers want to work in city centers. Therefore, those who work in rural areas wish to be appointed to schools in city centers. We can state that teachers working in city centers have high continuance commitment levels because they are satisfied with their place of duty.

Malik et al. conducted a study on teachers of a public university in Pakistan and reported that job satisfaction, pay satisfaction and quality of supervision positively affected organizational commitment and that work-itself, supervision, salary, coworkers and opportunities for promotion resulted in improved organizational commitment and satisfaction [37].

Dee et al. conducted a study on the organizational commitment of teachers in an urban school district and reported that participants had a medium level of organizational commitment and that teacher empowerment, school communication, work autonomy and teamwork correlated with each other. Participants' organizational commitment was mostly affected by teamwork and curriculum teamwork. They concluded that school commitment and organizational commitment can be achieved by instructional improvements, curriculum development, decision-making, strong external relations and teacher empowerment [38].

The literature emphasizes the importance of extra-role behaviors to achieve higher organizational commitment in team performance and to enable teachers to receive both external (wages and benefits) and internal (job satisfaction) rewards. It also suggests that extra-role behaviors can strengthen the relationship between teachers and schools [39] [40].

The national literature and the international literature report similar results both in terms of organizational commitment levels and in terms of variables affecting organizational commitment levels. We can state that especially educational planning, work environment, income and increased number of teacher activities improve organizational commitment.

In conclusion, some of the results of this study differ from those of previous studies conducted in Turkey. Participants' organizational commitment levels decreased especially with an increase in the number of years of experience. Research shows that teachers are more committed to their profession with an increase in the number of years of experience. Bağriyanık [41] conducted a study on the relationship between teachers' work values and organizational commitment, concluding that an increase in such work values as instrumental material, instrumental support and prestige increases organizational commitment as well. Deterioration in work values in the Turkish education system over the last years has reduced the commitment of teachers with many years of experience to their profession. it is possible to improve the effectiveness of the education system by improving teachers' working environment and conditions, and by finding solutions to their work-related problems. These improvements will also positively affect teachers' professional commitment and organizational commitment, and encourage them to develop skills and knowledge and use them in practice.

\section{REFERENCES}

[1] Leong, CS, Furnham, AE, Cooper, CL. (1996). The moderating effect of organisational commitment on the occupational stres outcome relationship. Human Relations, 49(10), 1345-1363.

[2] Mathews, BP, Shepherd, JL. (2002). Dimensionality of cook 
and wall's (1980) british organizational commitment scale. Journal of Occupational and Organizational Psychology, 75, 369-375.

[3] Mowday, R. T., Porter, L. W., and Steers, R. M. EmployeeOrganization Linkages: The Psychology of Commitment, Absenteeism, and Turnover, Academic Press, New York, 1982

[4] Seymen, AO. (2008). Örgütsel Bağl1lığı Etkileyen ÖrgütKültürü Tipleri Üzerine Bir Araştırma, Ankara: Detay Yayıncilik, 135.

[5] Allen, N. J., \& Meyer, J. P. (1990). Organizational socialization tactics: A longitudinal analysis of links to newcomers' commitment and role orientation. Academy of management journal, 33(4), 847-858.

[6] Maslach C. \& Leiter M.P. (1997). The truth about burnout: how organizations cause personal stress and what to do about it. San Francisco,CA: Jossey-Bass

[7] Balay, R. (2000). Özel ve Resmi Liselerde Yönetici ve Öğretmenlerin Örgütsel Bağlılı̆̆ı: Ankara ilii Örneği, Yayınlanmamıs Doktora Tezi, Ankara Üniversitesi, Sosyal Bilimler Enstitüsü, Ankara, ss.10-117.

[8] Balcı, A. (2003). Örgütsel sosyalleşme kuram strateji ve taktikler. Ankara: PegemYayıncılık.

[9] Özkan, V. (2008). Sınıf öğretmenlerinin bazı değişkenlere göre örgütsel bağl1lık düzeyleri (Sakarya İli Örneği. Sakarya: Sakarya Üniversitesi Sosyal Bilimler Enstitüsü .

[10] Brown, B. B. (2003). Employees' Organizational Commitment and Their Perceptions of Supervisors' Relations-Oriented and Task-Oriented Leadership Behaviors (Doctoral dissertation, Virginia Tech).

[11] Gören, T., Yengin Sarpkaya, P. (2014). İlköğretim kurumlarında görev yapan öğretmenlerin örgütsel bağlllık düzeyleri (Aydın ili örneği), Eğitim Bilimleri Dergisi, 40, s.69-87.

[12] Kurşunoğlu, A., Bakay E., Tanrı̈ğen A. (2010). İlköğretim okulu ögretmenlerinin örgütsel bağlilik düzeyleri. Pamukkale Üniversitesi Eğitim Fakültesi Dergisi, 28(28), 101-115.

[13] Akyol, P., Atan T., Gökmen, B. (2013). Beden Eğitimi Ve Sınıf Öğretmenlerinin Örgütsel Bağlılık Düzeylerinin İncelenmesi. Spor Ve Performans Araştırmaları Dergisi, 4(1).s.38-45.

[14] Korkmaz, HTE. (2010). İşte Yaşanan Olay kategorileri İle Duygu Durumları ve İşe yönelik tutumlar Arasındaki İlişkiler: Duygusal 0laylar Kuramının Test Edilmesi. Doktora Tezi. Orta Doğu Teknik Üniversitesi. Sosyal bilimler Enstitüsü. Psikoloji Bölümü. Psikoloji Anabilim Dal1, 71.

[15] Karakaya Y. E., Karademir, T. (2013). Beden Eğitimi Öğretmenlerinin Örgütsel Bağlılık Düzeyleri. Spor Bilimleri Dergisi, 24(1), 37-44

[16] Angle, H. L., \& Perry, J. L. (1981). An empirical assessment of organizational commitment and organizational effectiveness. Administrative science quarterly, 1-14.

[17] Mcclurg, LN. (1999). Organizational commitment in the temporary-help service industry. Journal of Applied
Management Studies, 8 (1), 5-26.

[18] Elizur, D. and Koslowsky, M., (2001)“Values and Organizational Commitment”. International Journal of Manpower, Vol.22, No.7, pp.593-599.

[19] Jackson, PR. (2004). Employee commitment to quality. International Journal of Quality and Reliabilty Management, 21 (4), 714-730.

[20] Kırel, Ç. (1999). Esnek çalışma saatleri uygulamalarında cinsiyet iş tatmini ve iş bağlılığ ilişkisi. İstanbul Üniversitesi İşletme Fakültesi Dergisi, 28 (2), 115-136

[21] Karrasch, A. I. (2003). Antecedents and consequences of organizational commitment. Military psychology, 15(3), 225-236.

[22] Danış, A. (2009). Anadolu teknik ve anadolu meslek lisesi öğretmenlerinin örgütsel bağl1lık düzeyleri (İzmit örneği)(Yayımlanmamış yüksek lisans tezi). Yeditepe Üniversitesi, İstanbul.

[23] Durna, U., Eren V. (2005). Üç Bağlılık Unsuru Ekseninde Örgütsel Bağlılık. Doğuş Üniversitesi Dergisi, 6(2), 210-219.

[24] Erdoğmuş, H. (2006). Resmi-özel ilköğretim okullarında çalışan yöneticilerin kişisel özellikleri ile örgütsel bağlılıkları arasındaki ilişki. Yayınlanmamış yüksek lisans tezi. İstanbul: Marmara Üniversitesi. Eğitim Bilimleri Enstitüsü. Eren, E.(2010). Örgütsel davranış ve yönetim psikolojisi, 12, 81-94.

[25] Boylu Y., Pelit E., Güçer E. (2007). Akademisyenlerin örgütsel bağl1lık düzeyleri üzerine bir araştırma. Finans Politik \& Ekonomik Yorumlar, 44(511), 55-74.

[26] Çakır, A. (2007). İlköğretim okullarında görev yapan ögrretmenlerin örgütsel bağlılık düzeyleri ve okul kültürü algıları arasındaki ilişkinin incelenmesi. Yeditepe Üniversitesi, İstanbul.

[27] Nartgün, Ş. S., \& Menep, İ. (2010). İlköğretim okullarında görev yapan öğretmenlerin örgütsel bağlılığa ilişkin alg1 düzeylerinin incelenmesi: Şırnak/İdil örneği. Uluslararası Insan Bilimleri Dergisi, 7(1), 288-316.

[28] Özcan, O. (2008). .İlköğretim Öğretmenlerinin Örgütsel Özdeşim, Örgütsel Bağlllık ve Örgütsel Vatandaşl1k Davranışlarının Demografik Özelliklere Göre İncelenmesi. Yeditepe Üniversitesi, Sosyal Bilimler Enstitüsü

[29] Özkaya, M. O., Kocakoç, İ. D., Kara, E. (2006). Yöneticilerin örgütsel bağl1lıkları ve demografik özellikleri arasındaki ilişkileri incelemeye yönelik bir alan çalışması. Yönetim ve Ekonomi: Celal Bayar Üniversitesi İktisadi ve İdari Bilimler Fakültesi Dergisi, 13(2), 77-96.

[30] Benkhoff, B. (1997). Disentangling organizational commitment: The dangers of the OCQ for research and policy. Personnel review, 26(1/2), 114-131.

[31] Gündoğan, T. (2009). Örgütsel bağl1lık: Türkiye Cumhuriyet merkez bankası uygulaması. Uzmanlık Yeterlilik Tezi, Türkiye Cumhuriyet Merkez Bankası İnsan Kaynakları Genel Müdürlüğü, Ankara.

[32] Selvitopu, A., Şahin, H. (2013). Ortaöğretim öğretmenlerinin örgütsel adalet algıları ile örgütsel bağlılıkları arasındaki ilişki. Ahi Evran Üniversitesi Kırşehir 
Eğitim Fakültesi Dergisi, 14(2).

[33] Demirsoy, E. (2009). Beden eğitimi öğretmenlerinin iş doyumu ve örgütsel bağlılıkları arasındaki ilişkinin incelenmesi. Bolu, Abant İzzet Baysal Üniversitesi Sosyal Bilimler Enstitüsü, Spor Yöneticiliği Anabilim Dalı.

[34] Yalçın, A., İplik F.N. (2005). Beş yıldızlı otellerde çalışanların demografik özellikleri ile örgütsel bağlılıkları arasındaki ilişkiyi belirlemeye yönelik bir araştırma. Çukurova Üniversitesi Sosyal Bilimler Enstitüsü Dergisi,14(1) 395-412.

[35] Canpolat, C. (2011). Öğretmen kariyer basamakları uygulaması ile öğretmen motivasyonu ve örgütsel bağlılık arasındaki ilişkiler. Yayımlanmamış yüksek lisans tezi. Fırat Üniversitesi. Elazığ.

[36] Kilıçoğlu, G. (2010). İlköğretim okulu öğretmenlerinin örgütsel bağlılık algılarının bazı değişkenler açısından incelenmesi. Unpublished master's thesis, Ege Üniversitesi, İzmir.

[37] Malik, M. E., Nawab, S., Naeem, B., \& Danish, R. Q. (2010). Job satisfaction and organizational commitment of university teachers in public sector of Pakistan. International journal of business and management, 5(6), 17-26.

[38] Dee, J. R., Henkin, A. B., Singleton, C. A. (2006). Organizational commitment of teachers in urban schools: Examining the effects of team structures. Urban Education, 41(6), 603-627.

[39] Becker, T., Billings, R. (1993). Profiles of commitment: An empirical test. Journal of Organizational Behavior, 14, 177-190.

[40] Scott, K., Townsend, A. (1994). Teams: Why some succeed and others fail. HR Magazine, 39(8), 62-67.

[41] Bağrıyanık, H. (2016). Öğretmenlerin İş Değerleri ile Örgütsel Bağlılık Düzeyleri Arasındaki İlişski. Türk Eğitim Bilimleri Dergisi, 14(1), 69-84. 